TITLE:

\title{
GAMMARIDEA AMPHIPODA OF THE INTERTIDAL REEF FLAT OF ISHIGAKI ISLAND, RYUKYU ARCHIPELAGO. - PART I. GENUS HYALE-
}

\section{$\operatorname{AUTHOR}(\mathrm{S}):$}

Hirayama, Akira

\section{CITATION:}

Hirayama, Akira. GAMMARIDEA AMPHIPODA OF THE INTERTIDAL REEF FLAT OF ISHIGAKI ISLAND, RYUKYU ARCHIPELAGO. -PART I. GENUS HYALE-. PUBLICATIONS OF THE SETO MARINE BIOLOGICAL LABORATORY 1980, 25(1-4): 131-156

\section{ISSUE DATE:}

1980-02-29

URL:

http://hdl.handle.net/2433/175988

RIGHT: 


\title{
GAMMARIDEA AMPHIPODA OF THE INTERTIDAL REEF FLAT OF ISHIGAKI ISLAND, RYUKYU ARCHIPELAGO. PART I. GENUS HYALE')
}

\author{
AKIRA HIRAYAMA \\ Amakusa Marine Biological Laboratory, Kyushu University, \\ Amakusa, Kumamoto 863-25, Japan
}

With Text-figures $1-17$

Systematic studies of gammaridean Amphipoda of Japan have been carried out in temperate waters of Japan proper (Iwasa 1939, Nagata 1959, 1960, 1965, 1966), however, there is no report on the gammaridean fauna of the Ryukyu Archipelago, at the southern end of Japan. In summer 1977, the present author had an oppotunity to visit Ishigaki Island, Yaeyama Group of Ryukyu Archipelago, and collected a small group of gammarideans in Kabira Bay. The collecting locality in the bay is situated on the southeast coast of the island $\left(24^{\circ} 27^{\prime} \mathrm{N}, 124^{\circ} 09^{\prime} \mathrm{E}\right)$ where fringing coral reef is well developed. Gammarid materials upon which this study is based were obtained from small algae growing on the reef flat.

In the collection, the author took an interest in the genus Hyale. Three species of the genus seemed to be new to science, some other undefined species of the genus are also included. Those species are described in the present paper, but the naming of the latter species is reserved for the future. Other species of the same collection will be described by the author elsewhere.

The author wishes to express his sincere thanks to Prof. T. Kikuchi of Amakusa Marine Biological Laboratory, Kyushu University, for giving him the chance to collect this material and for his critical reading of the manuscript. He also express his thanks to Dr. J. L. Barnard of Smithsonian Institution, U.S.A., for his kind advice and critical reading of the manuscript.

Hyale didendactyla sp. nov.

(Figs. 1-3)

\section{Description.}

Head: Lateral cephalic lobe truncate vertically. Eyes large, surrounding by one layer of clear ommatidia.

Antennae: Antenna 1 one third of body length, much shorter than antenna 2, flagellum with bifurcate setae. Antenna 2 very long, but shorter than body length.

1) Contributions from the Amakusa Marine Biological Laboratory, Kyushu University, No. 257. Publ. Seto Mar. Biol. Lab., XXV(1/4), 131-156, $1980 . \quad$ (Article 10) 


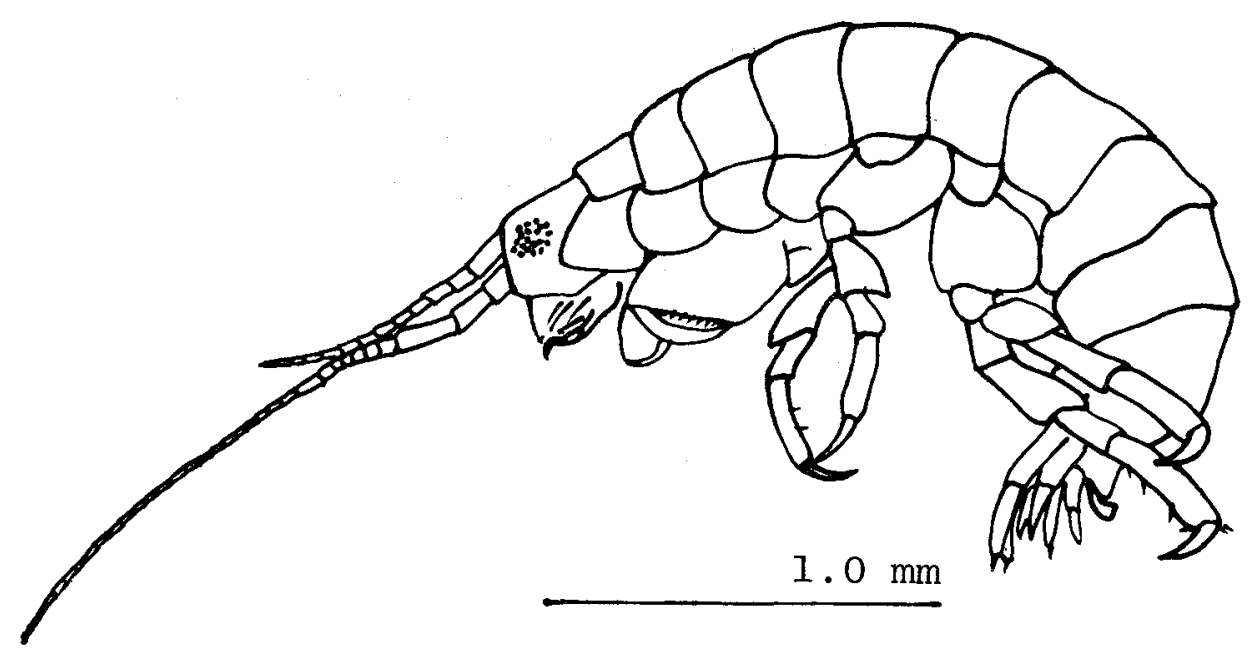

Fig. 1. Hyale didendactyla sp. nov, holotype (male $3.0 \mathrm{~mm}$ in body length). Lateral view of body.

Mouthparts: Inner plate of maxilliped with large apical tooth not exceeding half of article 2, outer plate with simple apical setae reaching half of article 2, base of dactyl about half of article 3, dactyl with short apical spine. Palp of maxilla 1 reaching slightly beyond outer plate, inner plate with two plumose setae and three minute setae on apical margin, outer plate with two types of spines, about ten setae and minute setae on apical margin. Inner margin of maxilla 2 with eight serrate spines and fifteen stout setae. Molar with one long plumose seta. Apical margin of upper lip and shoulder of lower lip thick-haired.

Gnathopod 1: Coxa 1 rectangular, lower margin weakly concave. Basis broad distally, with two spines on both margins. Carpus posterior lobe well developed, free lobe with about six setae, anterior distal margin with two setae. Propod with four plumose setae on facial surface. Palm with one row of many setae and one stout spine fitting between bifurcation of dactyl, defined by cusp. Dactyl bifurcate, with two spines on inner margin.

Gnathopod 2: Anterior margin of coxa 2 weakly expanded, sinuosity of posterior margin small. Posterior and anterior margins of basis almost straight, width slightly broader distally. Posterior lobe of carpus small, semi-circular. Palm with many setae, oblique, defined by two spines. Dactyl bearing setae regularly on inner margin, as long as palm.

Peraeopods: Each peraeopod with two serrate and stout locking spines. Peraeopod 1 similar to peraeopod 2, anterior margin of merus with three spines. Coxa 3 with expended lower margin, and weakly excavate and sinuate posterior margin. Merus anterior margin of peraeopod 2 with one spine, basis as long as merus and carpus, propod shorter than basis. Peraeopod 3 smaller than peraeopods 4-5. Posterior lobe of coxa 6 longer than anterior one. Sinuate posterior margin of coxa 7 with two setae, basis of peraeopod 5 broad, its sinuate expansion round, one stout spine coming 

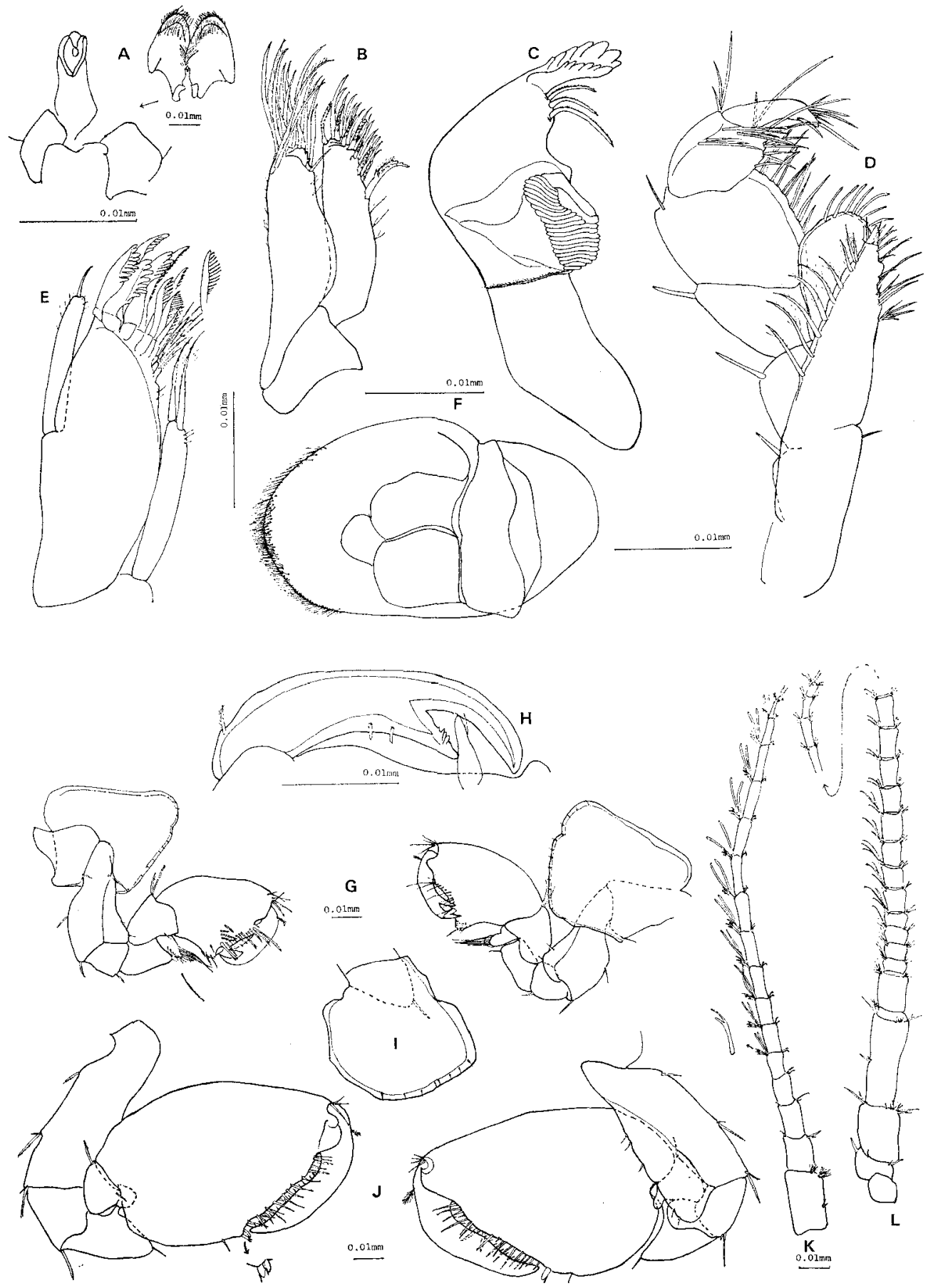

Fig. 2. Hyale didendactyla sp. nov., holotype (male $3.0 \mathrm{~mm}$ in body length). A, lower lip; B, maxilla 2; C, mandible; D, maxilliped; E, maxilla 2; F, upper lip; G, gnathopod 1; $\mathbf{H}$, dactyl of gnathopod 1 ; I, coxa 2; J, gnathopod 2; K, antenna 1; L, antenna 2 . 

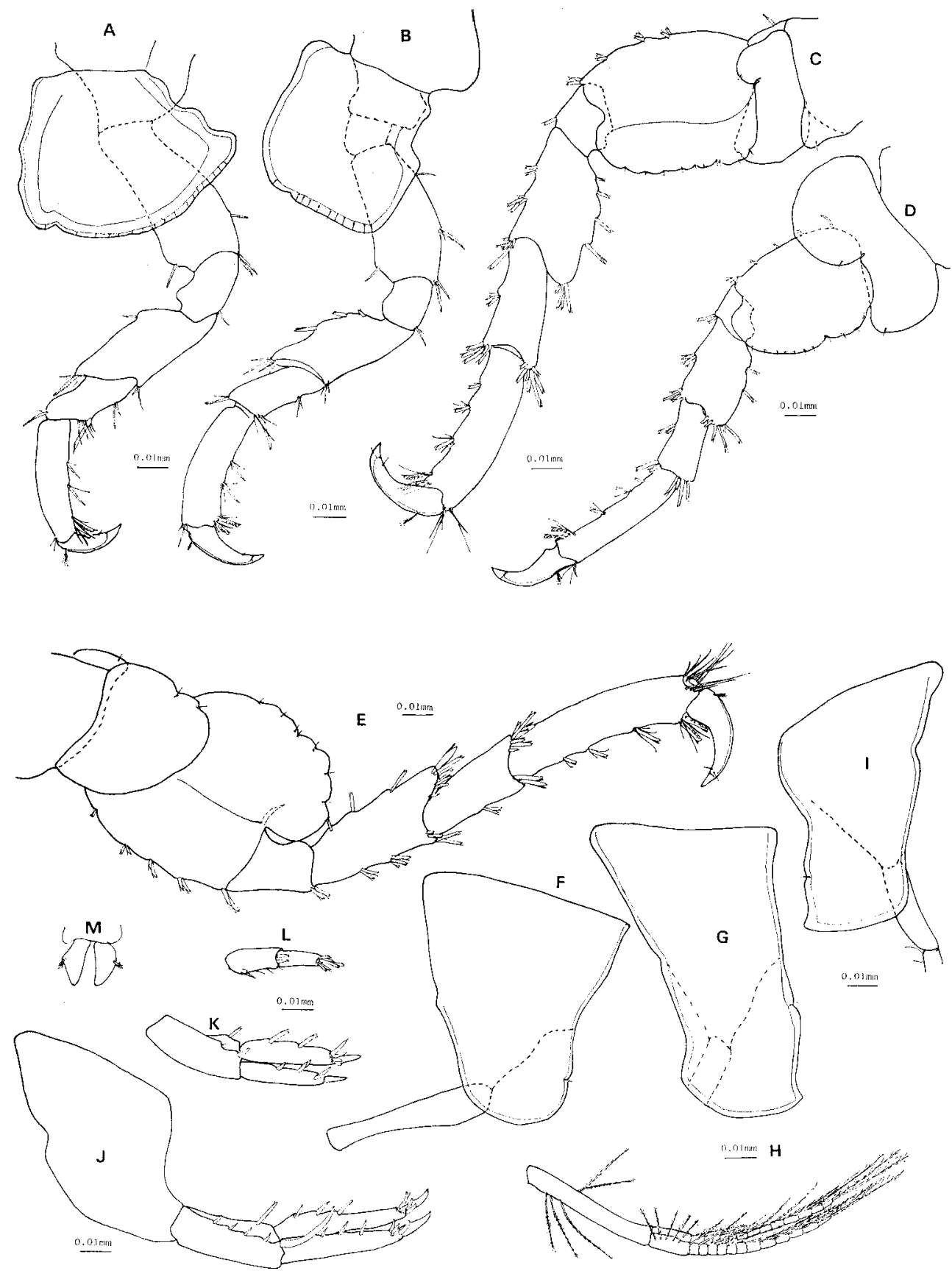

Fig. 3. Hyale didendactyla sp. nov., holotype (male $3.0 \mathrm{~mm}$ in body length). A, peraeopod 1 ; B, peraeopod 2; G. peraeopod 3; D, peraeopod 4; E, peraeopod 5; F, pleon 1; G, pleon 2, $\mathrm{H}$, pleopod 2; I, pleon 3; J, uropod 1; K, uropod 2; L, uropod 3; M, telson. 
out on center of its distal margin.

Pleon: Epimeron 1 semi-circular, posterior margin with one small seta. Posteroventral tooth of epimera 2-3 weak, posterior margins with one seta respectively.

Uropods: Peduncle of uropod 1 shorter than rami, with enlarged spine apicolaterally, both rami with three dorsal spines respectively. Peduncle of uropod 2 subequal to rami, inner ramus a little longer than outer one, with two dorsal spines, outer ramus with two dorsal spines. Peduncle of uropod 3 with two terminal spines and about six setae, subequal to ramus, ramus with six terminal spines.

Telson: Telson cleft completely, each lobe with one plumose seta.

Remarks.

Stebbing (1899) reported that Hyale diplodactylus Stebbing 1899 had a bifurcate dactyl of gnathopod 1 as well as this species, but it is difficult to compare this species to it in detail as he did not give it the detailed description and figures. Nevertheless, this species can be distinguished from it in the following points; in the $H$. diplodactylus, (1) palp of gnathopod 1 with wide pocket receiving dactyl but lacking a locking spine, (2) dactyl wider distally than at its basis and both teeth equal in length, (3) palm of gnathopod 2 long, oblique or nearly straight, defined by apparent mound with many setae but lacking a palmar spine, and etc.

Materials examined.

Holotype 1 male ( $3.0 \mathrm{~mm}$ in body length), paratype 4 males and other specimens 5 males. Intertidal small algae growing on coral reef of Kabira Bay, Ishigaki Island, Okinawa, Japan. July 1, 1977. These specimens are preserved in the collection of Amakusa Marine Biological Laboratory, Kyushu University.

\section{Hyale corallinacola sp. nov.}

(Figs. 4-6)

\section{Description.}

Head: Lateral cephalic lobe broad, truncate vertically. Eyes medium, purpule.

Antennae: Antenna 1 extending about half of antenna 2, aesthetascs developed. Antenna 2 two thirds of body length, not thick-haired.

Mouthparts: Setation of upper lip ordinary. Mandiblar molar with long plumose seta relatively developed, triturative. Palpar apex of maxilla 1 with one spine, outer plate having some long setae on facial angle. Dactyl of maxilliped not heavily setose, its apical spine medium, distal margin of article 2 heavily setose, inner plate with three conical teeth.

Gnathopod 1: Coxa 1 trapedium, posterior margin excavate proximally. Basis with two posterior spines in tandem, antero-distal projection developed and rounded. Postero-distal angle of merus poorly extended. Narrow lobe of carpus very developed, with some plumose setae. Palmar slope extended onto posterior margin by expansion near posterior seate. Palm with short and long setae defined by one stout spine. Propod with four plumose setae on surface level. Dactyl with 
some spines on inner margin.

Gnathopod 2: Coxa 3 rectangular, posterior margin remarkably excavate near upper margin. Antero-distal angle of basis expanded, with two minute spines, posterodistal angle with one minute seta and one spine produced. Ischium with strongly rounded anterior lobe. Apical margin of merus with one spine bulbous and extended, antero-distal margin with one spine. Propod ovate, with some setae on distal angle, having small convex with one small seta a little below palmar spine. Palm with many setae defined by two small stout spines. Apex of dactyl impinging into small and shallow palmar pocket, inner margin with about ten minute setae.

Peraeopods: Each peraeopod with two serrate and stout locking spines, each dactyl unguiculate. Coxa 3 rectangular, similar to coxa 2. Peraeopod 1 similar to peracopod 2 but a little longer than the latter, merus with four spines on anterior margin. Coxa 4 rectangular, sinuosity of posterior margin complex. Merus of peraeopod 2 with three spines on anterior margin. Both lobes of coxae 5-6 with minute seta, posterior lobe of coxa 6 larger than anterior one. Basis of peraeopod 3 ovate, posterior margin having one small concave with one minute seta, one of peraeopod 4 longer than width, peraeopod 4 larger than peraeopod 3, otherwise very similar to each other. Posterior margin of coxa 7 wider than anterior one, serrate posterior margin with three setae. Basis of peraeopod 5 circular, its postero-ventral lobe rounded and extended, otherwise similar to peraeopod 4.

Pleon: Epimeron 1 round, posterior margin with one minute seta. Anterior margin of epimeron 2 round, posterior margin with one minute seta sinuous weakly, having postero-ventral tooth. Epimeron 3 rectangular, having postero-ventral tooth, posterior margin sinuous weakly. Peduncle of pleopod 1 with three accessories on posterior angle.

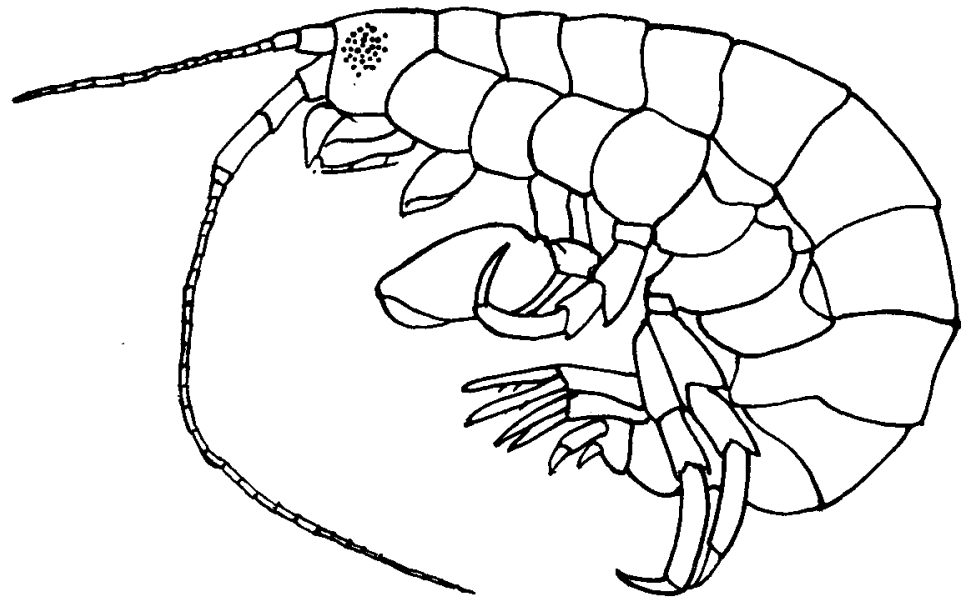

$1.0 \mathrm{~mm}$

Fig. 4. Hyale corallinacola sp. nov., holotype (male $4.2 \mathrm{~mm}$ in body length). Lateral view of body. 

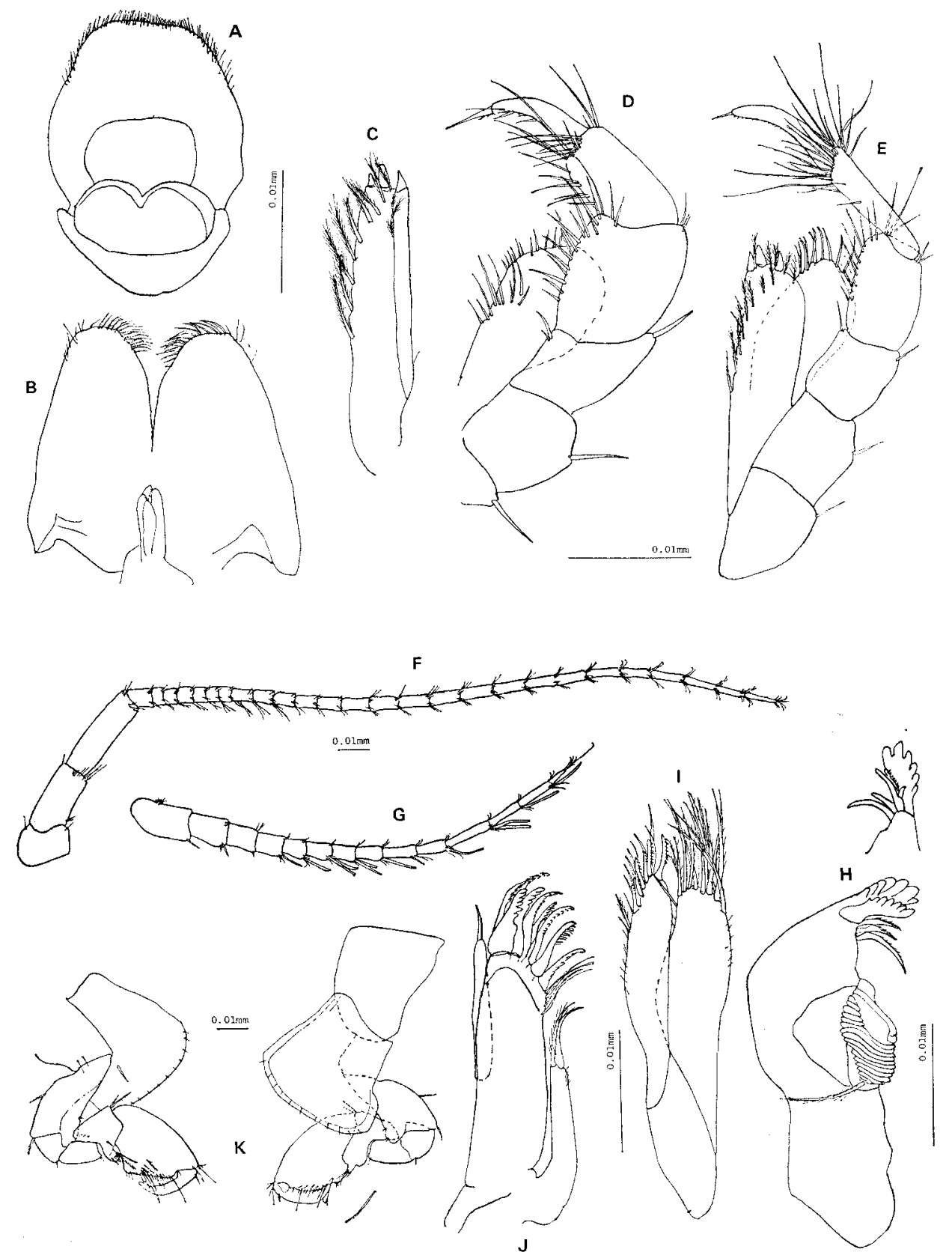

Fig. 5. Hyale corallinacola sp. nov., holotype (male $4.2 \mathrm{~mm}$ in body length). A, upper lip; B, lower lip; C, inner lobe of maxilliped; D, outer lobe and palp of maxilliped; E, maxilliped; F, antenna 2; G, antenna $1 ; \mathrm{H}$, mandible; I, maxilla $2 ; \mathrm{J}$, maxilla $1 ; \mathrm{K}$, gnathopod 1 . 

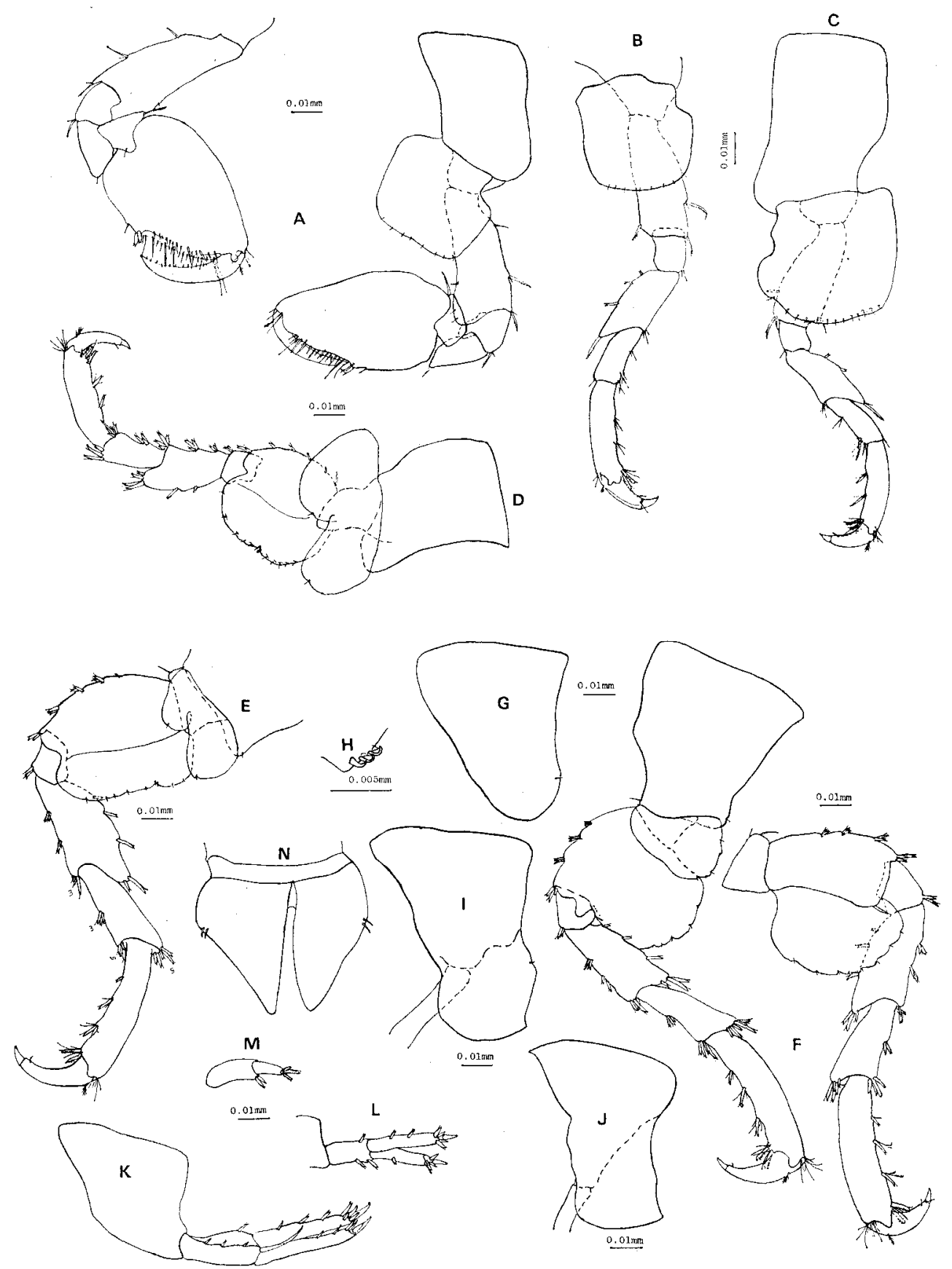

Fig. 6. Hyale corallinacola sp. nov., holotype (male $4.2 \mathrm{~mm}$ in body length). A, gnathopod 2; B, peraeopod 1; C, peraeopod 2; D, peraeopod 3; E, peraeopod 4; F, peraeopod 5; G, pleon $1 ; \mathrm{H}$, accessories of peduncle of pleopod $1 ; \mathrm{I}$, pleon $2 ; \mathrm{J}$, pleon $3 ; \mathrm{K}$, urosom 1 and uropod 1 ; and L, uropod $2 ; \mathrm{M}$, uropod. $3 ; \mathrm{N}$, telson 
Uropods: Peduncle of uropod 1 shorter than rami, with enlarged spine apicolaterally, with three spines on outer side and with one spine on inner side, outer ramus with lateral two spines, main terminal spine and three terminal spines, inner ramus with three lateral spines, main terminal spine and four terminal spines. Peduncle of uropod 2 shorter than rami, with two spines on outer side and one spine on inner side, inner ramus with two lateral spines, main terminal spine and four terminal spines, outer ramus with lateral spine, main terminal spine and three terminal spines. Peduncle of uropod 3 longer than ramus, with two terminal spines, ramus with main terminal spine and two terminal spines.

Telson: Telson completely cleft, each triangular, with proximal two setae.

\section{Remarks.}

This species can be discriminated from the following similar species by the following points: (1) in $H$. grandicornis Kroyer, both antennae short, strong tuft of setae existing immediately above molar process, palmar slope of gnathopod 1 defined by two stout spines, rami of uropod 3 as long as peduncle and having two or three spines dorsally, peduncle of uropod 3 with single spine on upper distal angle, (2) in $H$. rubra Thomson, basis of gnathopod 1 with two fine spines on each margin, propod of gnathopod 1 subrectangular, posterior margin of epimeron 3 with four or five minute spines, ramus of uropod 3 conical and half as long as peduncle, telson lacking setae and spines, (3) in $H$. schmidti (Heller), distal margin of upper lip convex, antenna 2 half as long as body, hind lobe of carpus of gnathopod 1 short and not extending beyond distal hind angle of merus, palm of gnathopod 1 defined by two spines, propod of gnathopod 2 having two spines near base of anterior margin, telson without setae and spines, (4) in $H$. gracilis Iwasa, palm defined by two stout spines, strong tuft of setae immediately above molar process, ramus of uropod 3 with one spine on lateral margin, (5) in $H$. honoluluensis Schellenberg, palm of gnathopod 2 fully occupying posterior margin of hand, (6) in H. yake J. L. Barnard, palm of gnathopod 2 humped near the base of dactyl and not having locking spines, propod of gnathopod 1 not having plumose setae on surface level.

\section{Materials examined.}

Holotype 1 male ( $4.2 \mathrm{~mm}$ in body length), paratype 5 males and other specimens 81 males. Intertidal small algae growing on coral reef of Kabira Bay, Ishigaki Island, Okinawa, Japan. July 1, 1977. These specimens are preserved in the collection of Amakusa Marine Biological Laboratory, Kyushu University.

\section{Hyale ishigakiensis sp. nov.}

(Figs. 7-9)

\section{Description.}

Head: Lateral cephalic lobe scarcely truncate, anterior cephalic part slightly sinuous. Eyes large. 
Antennae: Antenna 1 two thirds as long as antenna 2. Antenna 2 shorter than half of body length.

Mouthparts: Palp of maxilliped slender, dactyl with long terminal seta, outer plate not reaching article 3 of palp. Palp of maxilla 1 with one terminal seta beyond outer plate, apex of inner plate largely beyond base of palp. Molar of mandible with one plumose seta moderately developed.

Gnathopod 1: Coxa 1 expanding on lower margin, having two small cavities of which one has a minute seta anteriorly and the other has a small projection posteriorly. Medial and distal width of basis twice as broad as basal one, basis longer than propod. Antero-distal angle of carpus with two setae, posterior margin with seven setae and free lobe. Posterior margin of propod with four setae and fringe medially, ten plumose setae growing on medial level. Palm with a pair of stout spines, a pair of long setae and some short setae. Dactyl with three spines on inner margin overlapping palm.

Gnathopod 2: Coxa 2 rectangular, lower margin having small cavity posteriorly. Basis subequal to propod in length, distal margin with minute setae crenulate weakly and expanded strongly. Lobe of carpus with one stout spine near distal angle. Propod large, swelling and rectangular. Palm deeply concave, with a row of many spines run from dactyl base to end of palm onoutside. Dactyl with a row of many minute setae, apex blunt and reaching end of palm.

Peraeopods: Peraeopods with two locking spines, dactyls unguiculate. Peraeopods 1-2 resembling each other, slender in comparison with peraeopods 3-5. Basis of peracopods 3-5 winged largely, merus extended distally but one of peaeopod 5 not

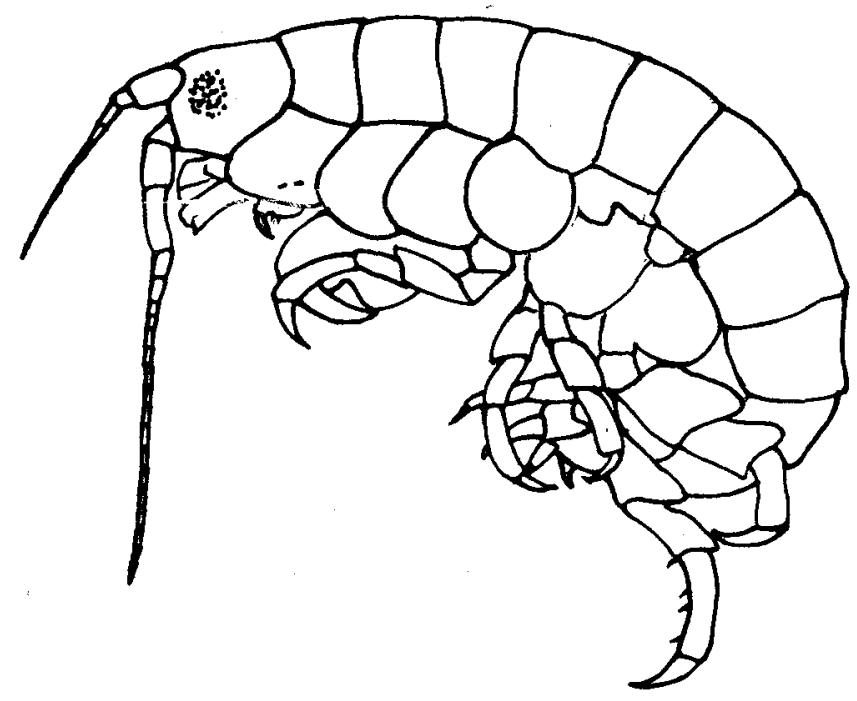

$1.0 \mathrm{~mm}$

Fig. 7. Hyale ishigakiensis sp. nov., holotype (male $4.0 \mathrm{~mm}$ in body length). Lateral view of body. 

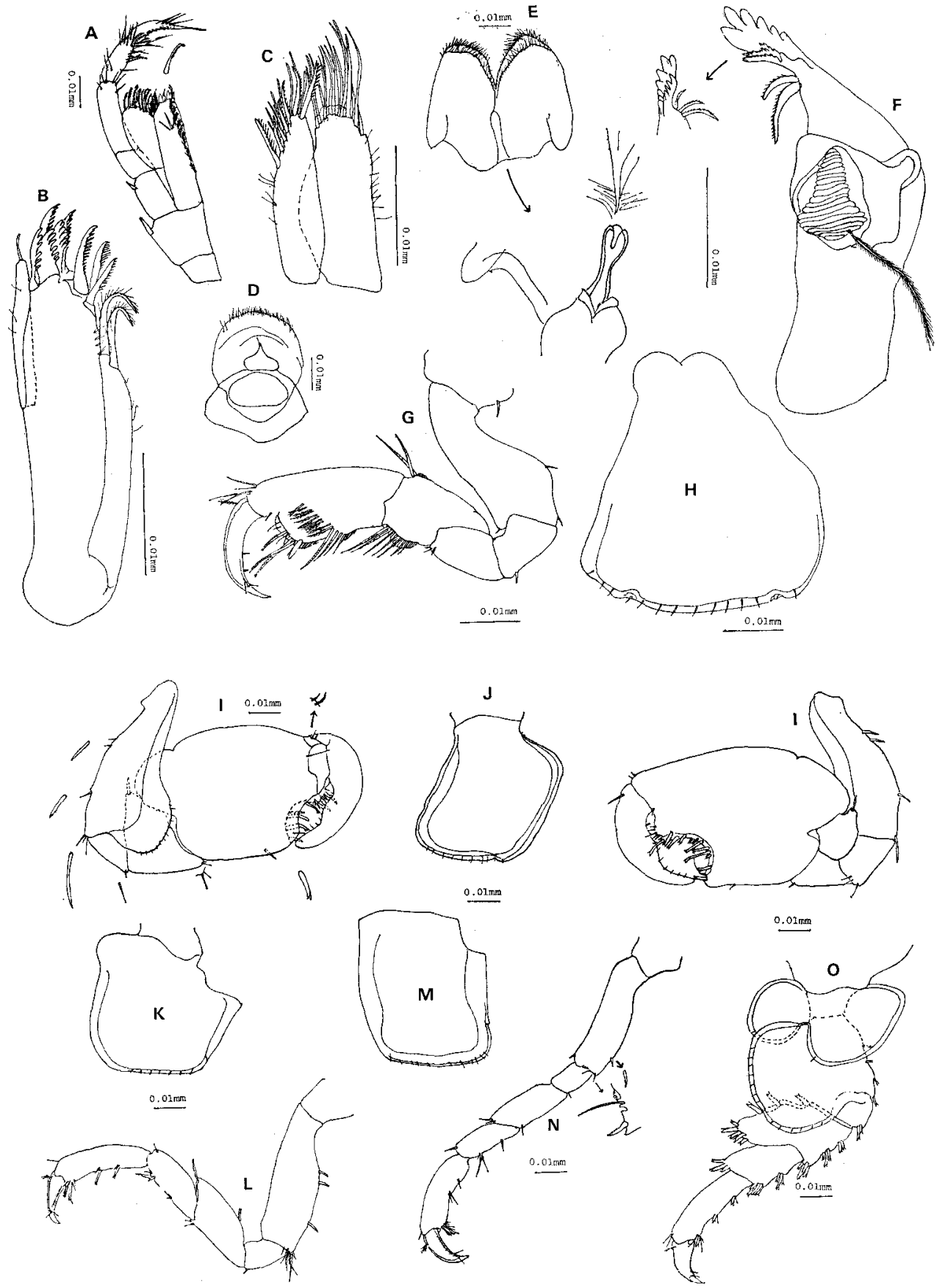

Fig. 8. Hyale ishigakiensis sp. nov., holotype (male $4.0 \mathrm{~mm}$ in body length). A, maxilliped; B, maxilla 2; C, maxilla 1; D, upper lip; E, lower lip; F, mandible; G, gnathopod 1; H, coxa 1; I, gnathopod 2; J coxa $2 ; \mathrm{K}$, coxa 3 ; L, peraeopod $1 ; \mathrm{M}$, coxa $4 ; \mathrm{N}$, peraeopod $2 ; \mathrm{O}$, peraeopod 3 . 


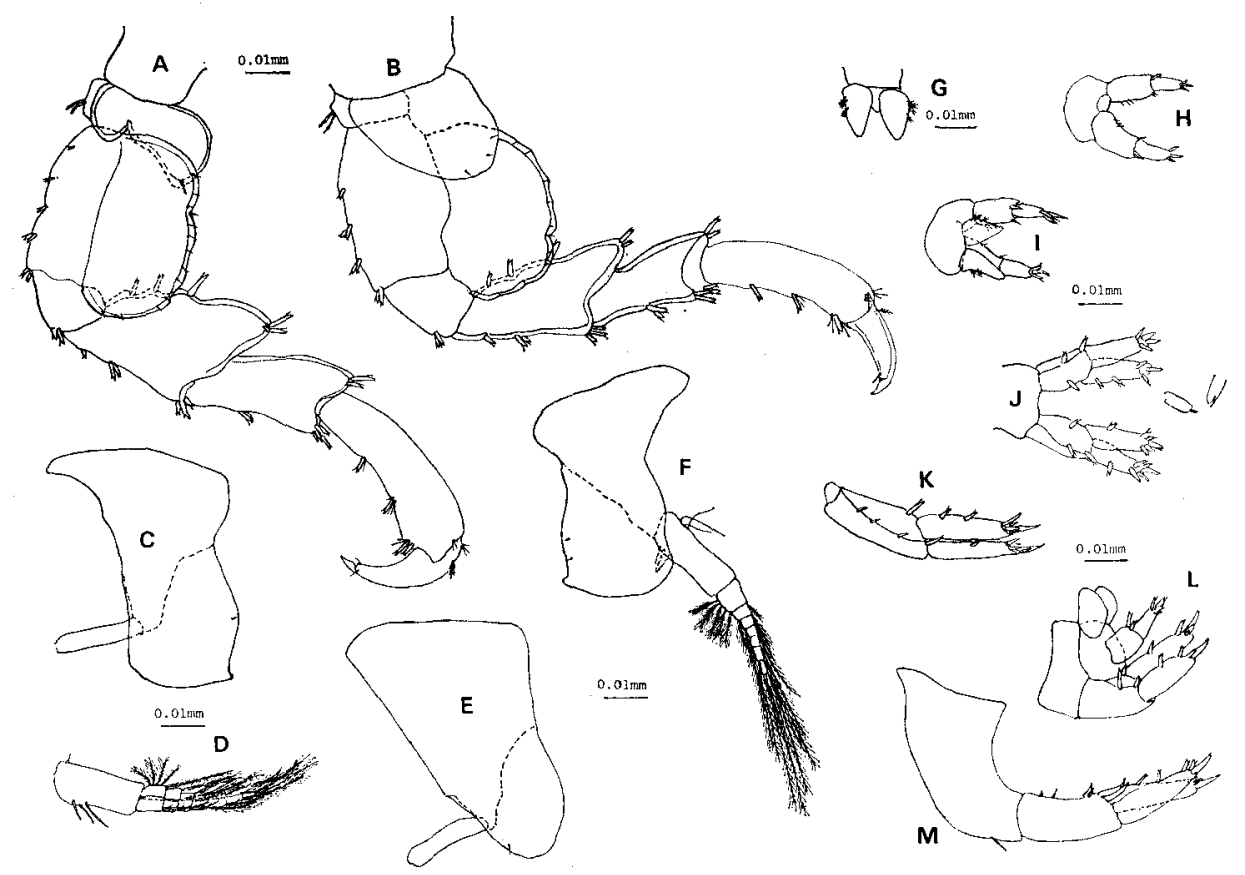

Fig. 9. Hyale ishigakiensis sp. nov., holotype (male $4.0 \mathrm{~mm}$ in body length). A, peracopod 4; B, peraeopod 5; C, pleon 2; D, pleopod 3; E, pleon I; F, Pleon 3 and pleopod 3; G, telson; $\mathrm{H}$, urosome 3 and uropod 3 ; I, urosome 3, uropod 3 and telson; $\mathrm{J}$, uropod 2; $\mathrm{K}$ and $\mathrm{M}$, uropod 1 and urosome 1; L, urosome 2, urosome 3, uropod 2, uropod 3 and telson.

conspicuous, distal margin of carpus broader than base. Coxa 3 rectangular. Coxa 4 having sinuous excavation on posterior margin. Posterior lobe of coxae 5-6 larger than anterior lobe. Lower margin of coxa 7 round, with three minute setae.

Pleon: Epimeron 1 semi-circular, with one minute seta on anterior margin. Epimerons 2-3 resembling each other, having blunt tooth on postero-distal angle and slightly convex posterior margin with one or two minute setae.

Urosome and uropods: Urosome 1 bearing one spine on lower margin. Uropod 1 with a large spine apicomedially on peduncle. Rami of uropods 1-2 subequal to each peduncle. Peduncle of uropod 3 longer and broader than ramus, with two distal spines and setae, and three lateral setae, ramus with three terminal spines.

Telson: Telson completely cleft, with three plumose setae on each lobe, sharply triangular, but its apex round.

\section{Remarks.}

This species resembles to Hyale grenfelli Chilton in the external appearance but can be distinguished from the latter by following points: (1) outer plate of maxilliped reaching to article 3 of palp, its terminal seta very short, (2) carpus of gnathopod 1 with five plumose setae on antero-distal angle, its post free lobe having fringe of about eight plumose setae, propod having fringe of ten setae medially on posterior margin and five plumose setae on surface level, (3) basis of gnathopod 2 expanding a little to 
lobe, dactyl not reaching near end of palm, (4) both lobes of coxa 5 subequal, (5) propod of peraeopods 1-2 as long as basis, (6) basis of peraeopod 4 wider than length, (7) peraeopod 5 longer than peraeopod 4, basis narrow and maximal width two third as long as length, (8) peduncle of pleopods with numerous setae, (9) inner ramus of uropod 2 larger than outer one as long as peduncle, peduncle with two distal spines, (10) uropod 3 bearing row of about nine setae medially on surface, (11) telson lacking spines and setae. Also, this species resembles $H$. waimea J. L. Barnard but can be distinguished apparently from the latter by the following points; (1) dactyl terminal seta of maxilliped very long, (2) sinuous line of palm in gnathopod 2 and so on.

Materials examined.

Holotype 1 nale ( $4.0 \mathrm{~mm}$ in body length), paratype 5 males and other specimens 46 males. Intertidal small algae growing on coral reef of Kabira Bay, Ishigaki Island, Okinawa. July 1, 1977. These specimens are preserved in the collection of Amakusa Marine Biological Laboratory, Kyushu University.

\section{Hyale sp. (No. 1)}

(Figs. 10, 11, 13(A-I, R))

\section{Description.}

Head: Lateral cephalic lobe, truncate vertically. Eyes medium.

Antennae: Antenna 1 smaller than half of antenna 2, peduncle 1 with plumose setae on lateral margin, flagellums with aesthetascs. Antenna 2 longer than half of body length, article 3 with two distal plumose setae.

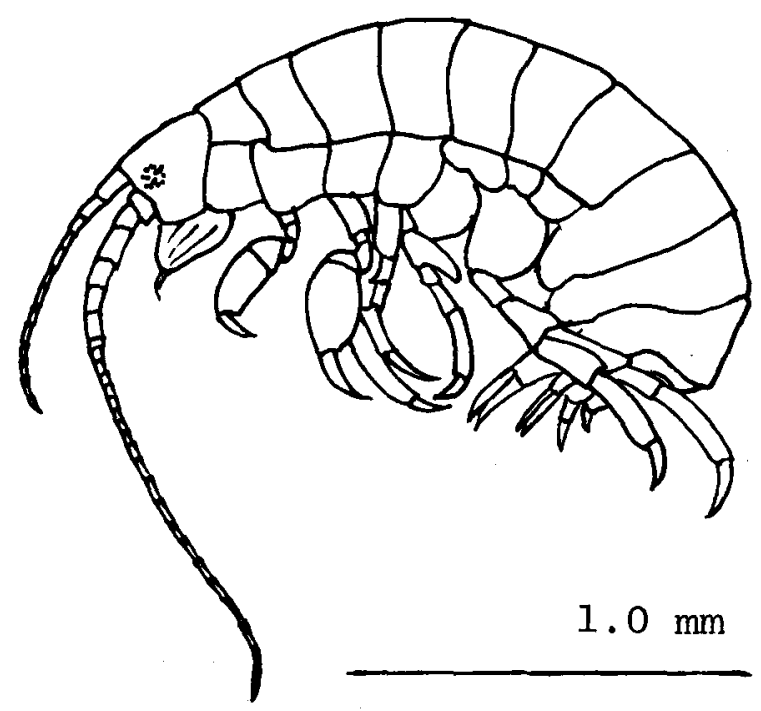

Fig. 10. Hyale sp. (no. 1), (male $3.0 \mathrm{~mm}$ in body length). Lateral view of body. 

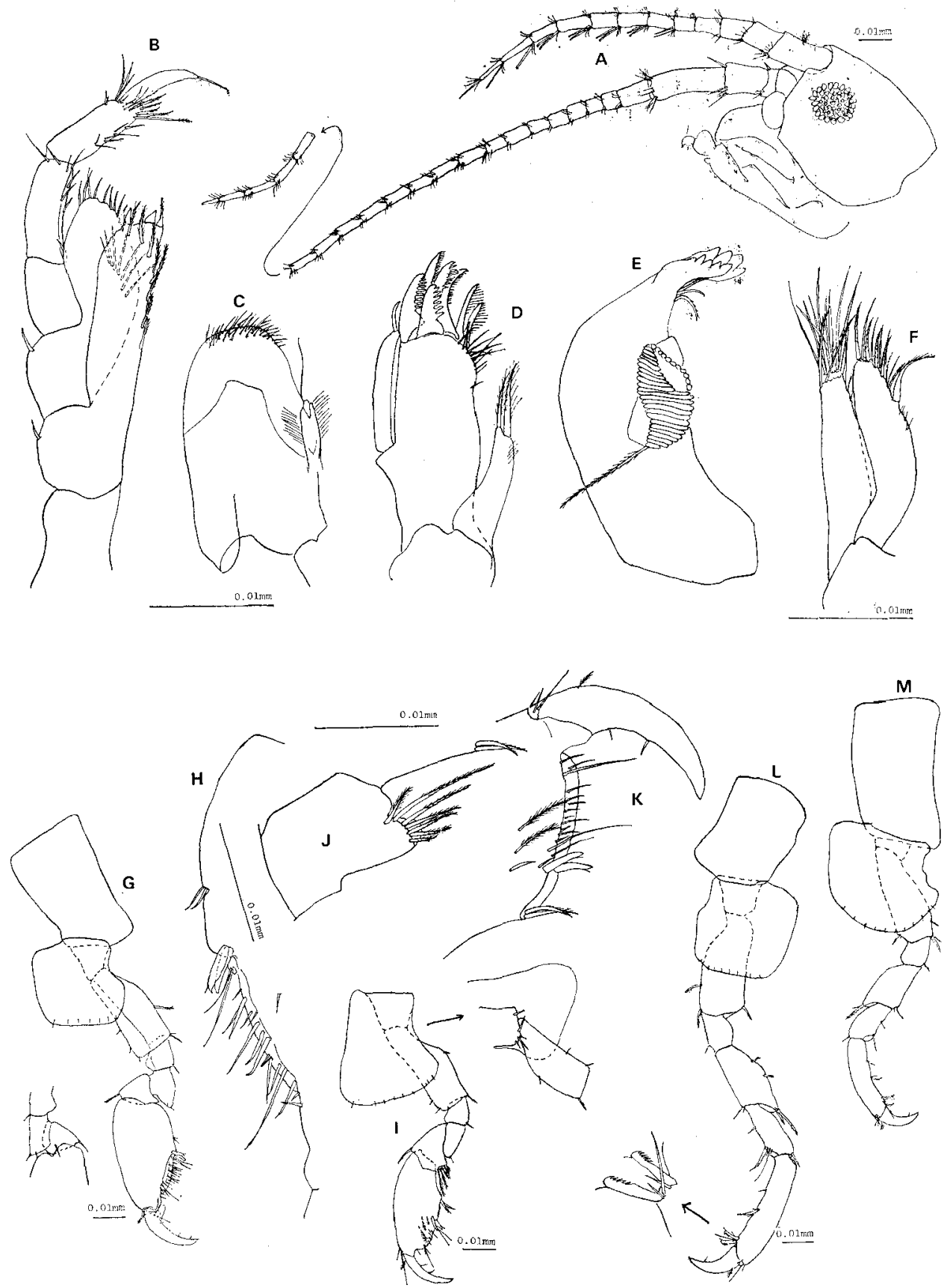

Fig. 11. Hyale sp. (no. 1), (male $3.0 \mathrm{~mm}$ in body length). A ,head, antenna 1 and antenna 2; B, maxilliped; C, lower lip; D, maxilla 1; E, mandible; F, maxilla 2; G, gnathopod 2 and peraeon 2; H, palm of gnathopod 2; I, gnathopod 1; J, carpus of gnathopod 1; K, palm and dactyl of gnathopod $1 ; \mathrm{L}$, peraeon 3 and peraeopod $1 ; \mathrm{M}$, peraeon 4 and peraepod 2. 
Mouthparts: Inner plate of maxilliped with three conical teeth, reaching to half of palpar article 2, outer plate beyond half of palpar article 2, lateral margin of dactyl smooth, its apical seta about half of dactyl. Palp of maxilla 1 beyond base of outer plate, with one apical seta, inner distal margin of inner plate with many setae. Molar of mandible developed medially, with many setae.

Gnathopod 1: Coxa 1 trapedium, posterior margin gently concave. Posterior lobe of carpus developed but not beyond posterior margin of merus, with seven plumose setae. Carpus with antero-distal spine. Propod rectangular, with three setae on face level. Palm defined by two stout spines, with many setae, palmar slope extended onto small expansion with two plumose setae. Dactyl as long as palm, with two minute setae on inner margin.

Gnathopod 2: Coxa 2 rectangular, posterior margin concave. Basis with lateral plumose seta, a set of distal plumose and minute setae on posterior margin, with three minute setae on anterior margin. Ischium with postero-distal setae, anterior expansion small. Posterior expansion of merus developed, receiving basal posterior angle of propod, with two minute setae. Carpus triangular, with antero-distal plumose seta. Propod about as long as basis, postero-distal margin with two plamose setae. Palm very oblique, about half of propod in length, defined by two stout spines, with many setae. Dactyl as long as palm, with three minute setae on inner margin.

Peraeopod 1: Coxa 3 rectangular, gentle concave of posterior margin not remarkable. Basis with lateral plumose seta, a set of distal plumose seta and simple minute seta on posterior margin, with antero-distal plumose seta. Merus with two lateral spines in tandem and two distal setae on anterior margin, with two simple postero-distal setae. Carpus as long as merus, with antero-distal seta, postero-lateral seta, and a set of one stout and long spine and three setae on postero-distal angle. Propod longer than basis, with one seta, a set of one spine and two setae, a set of two locking spines and three setae on posterior margin, with three simple setae on posterodistal angle. Dactyl unguiculate, with one seta on inner margin and one plumose seta on outer margin.

Peraeopod 2: Coxa 4 not rectangular, lower margin convex, sinuous posterior margin remarkable. Peraeopod 2 smaller than peraeopod 1, merus without anterolateral spine, otherwise very similar to peraeopod 1 .

Peraeopod 3: Both lobes of coxa 5 subequal in size, with one minute seta respectively. Basis longer than witdh, posterior margin weakly concave, with one seta, postero-distal angle round and produced, anterior margin with four spines in tandem. Merus with one lateral spine, equal to carpus in length. Propod subequal to basis in length, with two lateral spines and two locking spines on anterior margin, with four postero-distal setae. Dactyl unguiculate, with one seta on inner margin.

Peraeopod 4: Both lobes of coxa 6 having small concave with minute setae, posterior lobe more than twice as long as anterior one. Peraeopod 4 very similar to peraeopod 3, but larger than the latter. Basis longer than width, having small concave with one small plumose seta, postero-distal lobe round and developed remrkablly. 
Merus with three lateral spines in tandem and three distal spines on posterior margin. Propod as long as basis, with two locking spines. Dactyl unguiculate, with one minute seta on inner margin.

Peraeopod 5: Coxa 7 semi-circular, crenulate posterior margin with three minute setae. Basis ovate, posterior margin undulated, postero-distal margin round, developed medially, inner side with one stout spine near center of distal margin. Merus with three lateral spines in tandem on posterior margin, with single spine and a set of two spines on antero-distal margin, with three spines on both distal angle respectively. Carpus with two lateral spines and five distal spines on anterior margin, with six distal spines on posterior margin. Propod with three spines in tandem on antero-lateral margin and two locking spines. Dactyl unguiculate, with one minute seta on inner margin.

Pleon: Epimeron 1 round, having small concave with minute seta on posterior margin. Epimerons 2-3 with small postero-ventral tooth, having small concave with minute seta on posterior margin.

Uropods: Peduncle of uropod 1 shorter than rami, with one enlarged spine apicolaterally, three lateral spines on outer margin and one lateral spine on inner margin, both rami with two lateral spines and three spines respectively. Peduncle of uropod 2 subequal to rami in length, with two lateral spines on outer margin, one lateral spine on inner margin, both rami with two lateral spines and three or four terminal spines. Peduncle of uropod 3 subequal to rami in length, with two distal spines, rami with four terminal spines.

Telson: Telson cleft completely, each plate triangular, with seta medially.

Remarks.

This specimen can be distinguished from the proceding resembling species in the following points: (1) in $H$. media (Dana), peraeopods with ephebic obsolescence of the distal locking spines, palmar slope of gnathopod 1 defined by two stout spines, dactyl overlapping palm, distal angle of coxa 2 imperceptible, ramus of uropod 3 shorter than peduncle, (2) in $H$. schmidti (Heller) propod of gnathopod 1 somewhat triangular, broadest at base, with setal bundle on posterior margin, finger curved strongly, overlapping the ill-defined and very obloque palm, basis of gnathopod 2 with lamella expansion on anterior magin, ramus of uropod 3 shorter than peduncle.

I refrain from establishing a new species herewith, because only a single specimen was collected.

\section{Material examined.}

1 male (about $3 \mathrm{~mm}$ in body length), intertidal small algae growing on coral reef of Kabira Bay, Ishigaki Island, Okinawa, Japan. July 1, 1977. This specimen is preserved in the collection of Amakusa Marine Biological Laboratory, Kyushu University.

$$
\text { Hyale sp. (No. 2) }
$$

(Figs. 12, 13(J-Q), 14)) 


\section{Description.}

Head: Lateral cephalic lobe broad, truncate obliquely, weakly excavate. Eyes medium.

Antennae: Both antennae very short, about one fourth of body length, antenna 2 a little longer than antenna 1 . Peduncle 1 of antenna 1 bearing two plumose setae proximally on anterior margin, aesthetascs growing from segment 5. Peduncles 2-3 of antenna 2 bearing some plumose setae on distal margin, small brush of setae formed on distal margin of each article of flagellum.

Mouthparts: Mandibular molar heavily tritulate, lacking accessory blades. Palp of maxilla 1 with stout terminal seta. Inner plate of maxilliped with four conical teeth, apical seta of dactyl very short.

Gnathopod 1: Coxa 1 rectangular, longer than width. Width of basis wider than half of length, with one spine on postero-distal margin, one spine on posteroproximal margin and one spine on antero-distal margin. Ischium less than half of basis length, sub-rectangular, with one spine on postero-distal angle. Posterior lobe of carpus with five plumose setae developed, antero-distal angle with long plumose seta. Propod rectangular, with four plumose setae and free lobe proximally on posterior margin, with four plumose setae on face level. Palm transverse, defined by one stout spine and small one, with two long setae and some short setae. Dactyl overlapping palm very well, impinging between palmar spines and proximal free lobe.

Gnathopod 2: Coxa 2 rectangular, posterior margin sinuous, posterior angle having small tooth with minute seta. Basis with three spines in tandem on posterior margin, with one spine and two setae on distal angle and numerous minute setae on posterior margin of which round distal angle projects. Merus subrectangular, distal margin concave, postero-distal angle with one small spine produced downward somewhat. Carpus reniform. Propod ovate, with a few small setae on distal angle, posterior margin almost straight, with one small seta proximally. Palm oblique, defined by two small stout spines, with seven spines and some setae. Dactyl with five minute

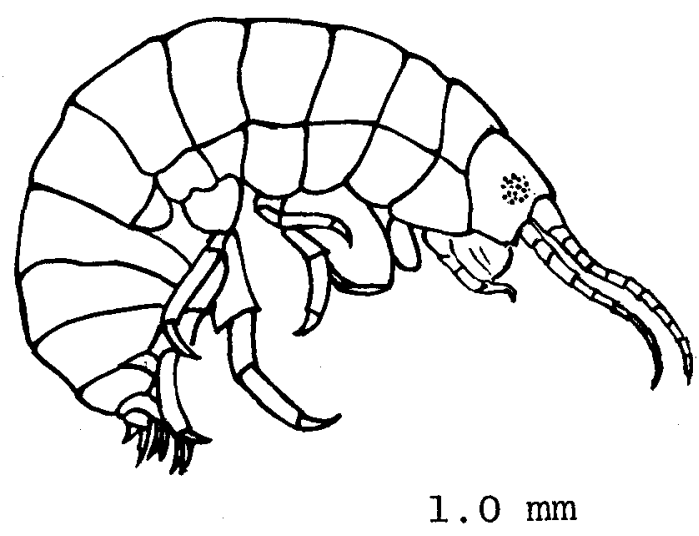

Fig. 12. Hyale sp. (no. 2), (2.5 mm in body length). Lateral view of body. 

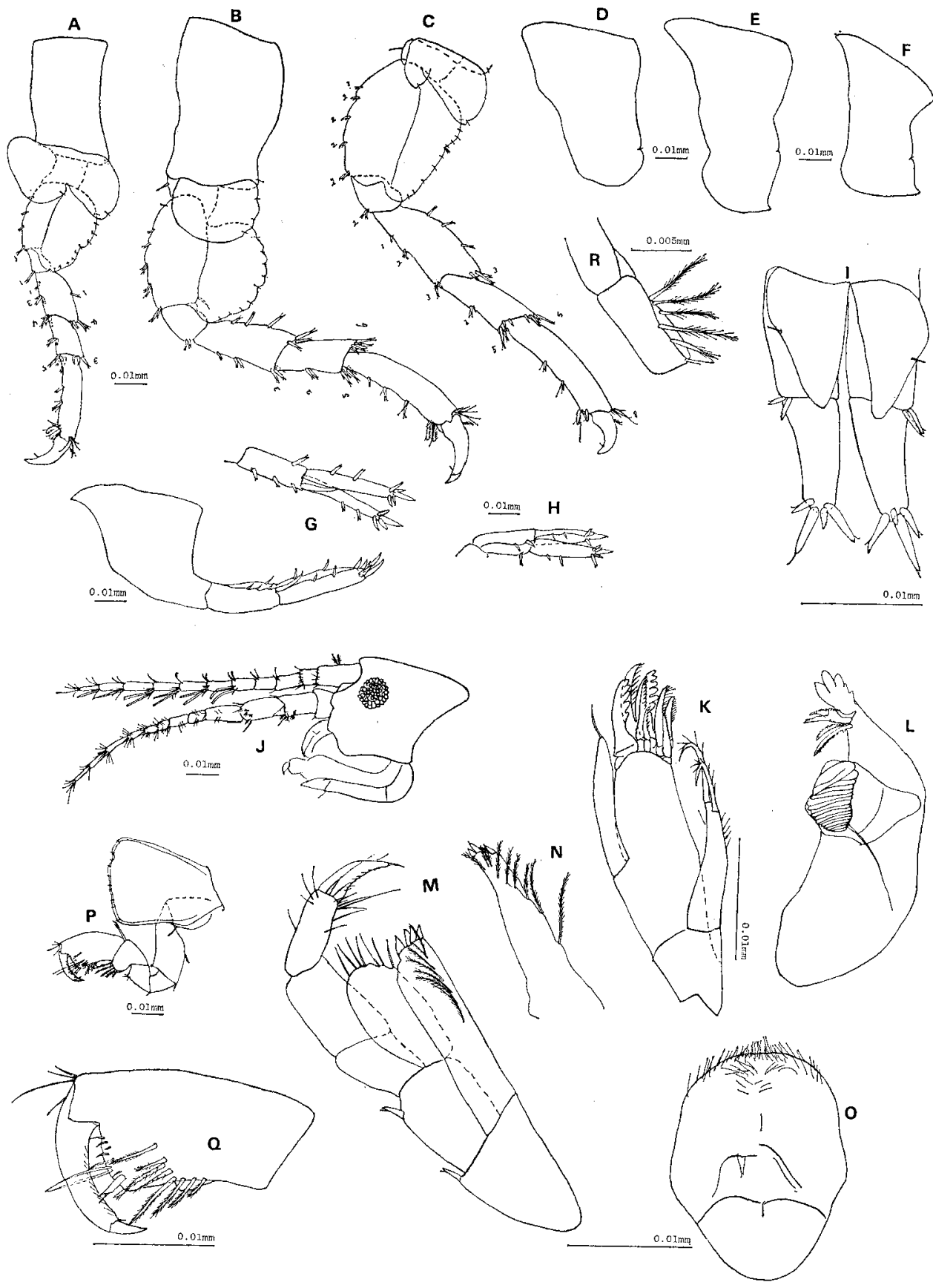

Fig. 13. Hyale sp. (no. 1), ( $3.0 \mathrm{~mm}$ in body length). A, peraeopod 3 and peraeon 5 ; B, peraeopod 4 and peracon 6 ; C, peraeopod 5 and peraeon 7 ; D, pleon 1 ; E, pleon 2; F, pleon 3; $\mathrm{G}$, urosome 1 and uropod $1 ; \mathrm{H}$, uropod 2; I, uropod 3 and telson; R, peduncle of pleopod 1 . Hyale sp. (no. 2), (2.5 mm in body length). J, head, antenna 1 and antenna $2 ; \mathrm{K}$, maxilla 1; L, mandible; $M$, maxilliped; $N$, inner lobe of maxilliped; $O$, upper lip; $P$, gnathopod 1; $Q$, propod and dactyl of gnathopod 1 . 
setae on inner margin and one plumose seta on outer margin.

Peraeopod 1: Coxa 3 similar to coxa 2. Basis with one spine on posterior margin and four setae on postero-distal angle. Propod with two setae proximally and two
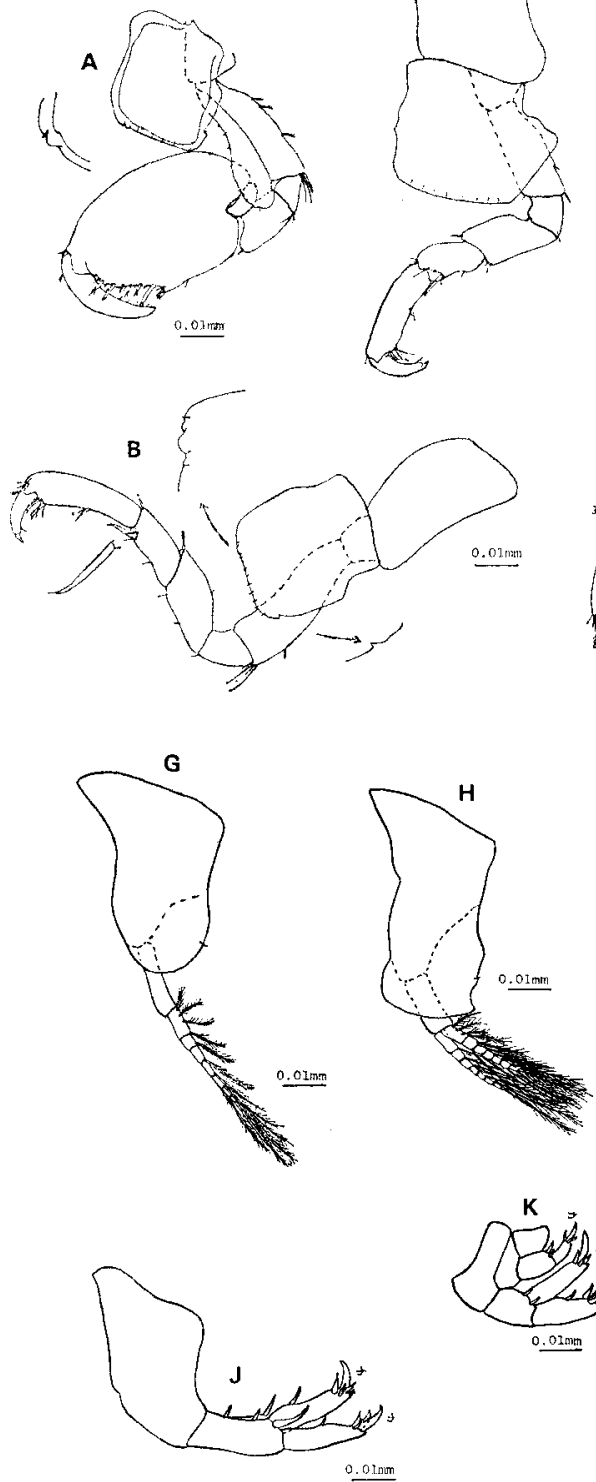
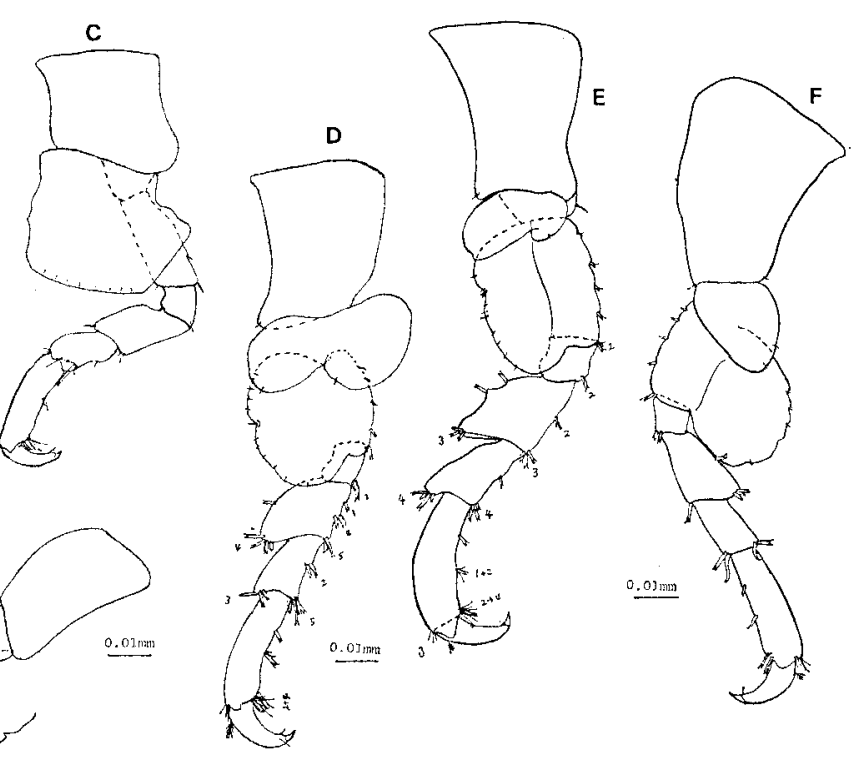
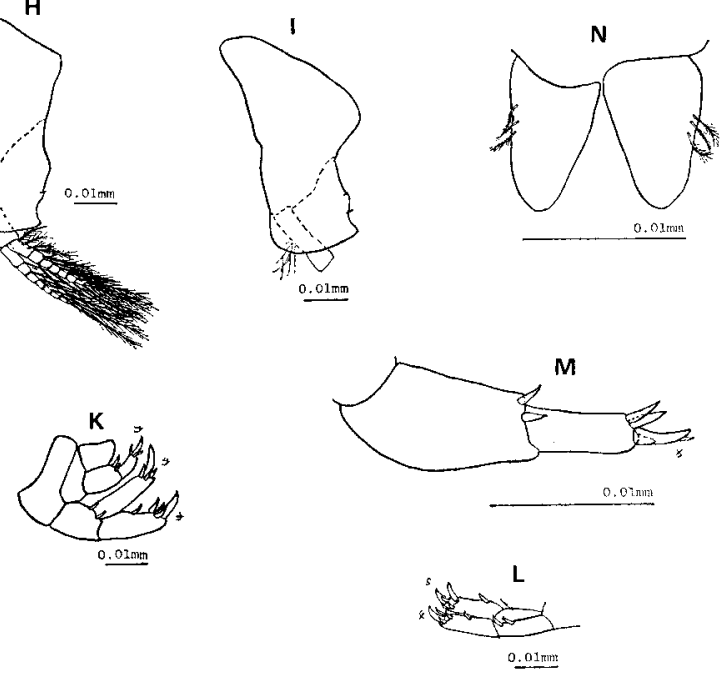

Fig. 14. Hyale sp. (no. 2), (2.5 mm in body length). A, gnathopod 2; B, peraeopod 1 and peraeon 3 ; $\mathrm{C}$, peraeopod 2 and peraeon 4; D, peraeopod 3 and peraeon 5 ; $\mathrm{E}$, peraeopod 4 and peraeon 6; F, peraeopod 5 and peraeon $7 ; \mathrm{G}$, pleon 1 and pleopod 1; $\mathrm{H}$, pleon 2 and pleopod 2; I, pleon 3; J, urosome 1 and uropod 1; K, urosome 2, uropod 2, urosome 3, uropod 3 and telson; L, uropod 2; M, uropod 3; N, telson. 
locking spines on posterior margin. Dactyl unguiculate, with one minute seta on inner margin.

Peraeopod 2: Coxa 4 wider than depth, posterior margin very expanded proximally. Peraeopod 2 very similar to peraeopod 1.

Peraeopod 3: Coxa 5 bilobed, both lobes subequal to each other in size, with one minute seta respectively. Posterior margin of basis having small concave, with minute spine. Ischium with two spines on postero-distal angle. Merus produced anterodistally, wider than length, with one proximal spine and four distal spines on anterior margin, with single spine, a set of two spines and five distal spines in tandem on posterior margin. Carpus with a pair of two lateral spines and five distal spines on posterior margin and three distal spines on anterior margin. Propod with two spines in tandem and two locking spines on posterior margin. Dactyl unguiculate, with one minute seta on inner margin and one plumose seta on outer margin.

Peraeopod 4: Coxa 6 bilobed, posterior lobe larger than anterior one. Basis longer than width, having small concave with one plumose seta, postero-distal angle with two spines. Distal margin of merus twice as wide as basal one, merus with two spines in tandem, and distal three spines on anterior margin, a set of two spines proximally and distal three spines on posterior margin, otherwise similar to peraeopod 3.

Peraeopod 5: Coxa 7 subtriangular, longer than width, with two setae on posterior margin. Crenulate posterior lobe of basis very expanded, reaching to about half of merus, with minute setae. Distal margin of merus not twice as wide as basal one, merus with one distal spine on posterior margin. Carpus with two distal spines on posterior margin and two distal spines on anterior margin. Propod with two spines in tandem, two locking spines on posterior margin and five minute setae on antero-distal angle. Dactyl unguiculate, with one minute seta on inner margin and one plumose seta on outer margin.

Pleon: Epimeron 1 round, with one seta on posterior margin. Epimeron 2 rectangular, having postero-ventral round tooth and sinuous posterior margin with one minute seta. Epimeron 3 similar to epimeron 2 except for two minute setae on posterior margin.

Urosome and uropods: Peduncle of uropod 1 subequal to rami in length, with enlarged spine apicomedially, both rami with one proximal spine and four terminal spines respectively. Uropod 2 very similar to uropod 1 except for smaller than uropod 1. Peduncle of uropod 3 with two distal spines, ramus shorter and narrowre than peduncle, with four terminal spines.

Telson: Telson completely cleft, each lobe triangular, with three plumose seta on proximal outer margin.

Remarks.

This specimen resembles $H$. media (Dana) but can be distinguished from the latter in the following points; (1) coxa 1 wider than olepth, triangular process medially, (2) distal angle of coxa 2 forming imperceptible triangulra process, (3) propod of gnathopod 2 ovate, almost triangular, (4) ephebic obsolescence of the distal locking spines on 
peraeopods $1-5,(5)$ uropod without enlarged spine apicomedially on peduncle.

I refrain from establishing a new species herewith, because only a single specimen was collected.

\section{Material examined.}

1 male $(2.5 \mathrm{~mm}$ in body length), intertidal small algae growing on coral reef of Kabira Bay, Ishigaki Island, Okinawa, Japan. July 1, 1977. This specimen is preserved in the collection of Amakusa Marine Biological Laboratory, Kyushu University.

\section{Hyale sp. (No. 3)}

(Figs. 15-17)

\section{Description.}

Head: Lateral cephalib lobe truncate vertically. Eyes relatively small.

Antennae: Antenna 1 one third of antenna 2, peduncle 1 with one plumose seta on anterior margin, flagellum with aesthetascs. Antenna 2 about half of body length, not heavy setae.

Mouthparts: Inner plate of maxilliped reaching half of palp article 2, with four conical teeth, outer plate reaching near the distal margin of article 2, dactyl equal to article 2 or 3 , its apical seta about half of dactyl. Palp of maxilla 1 beyound outer plate, with single apical seta and slender setae, anterior margin of outer plate with minute setae, mandibular process not devloped. Apical margin of upper lip flat, with many minute setae. Mandibular molar triturating, lacking accessory blades.

Gnathopod 1: Coxa 1 expanded posteriorly, excavate moderately. Basis with two postero-distal setae. Width of ischium narrower than distal margin of basis, with two postero-distal setae. Distal margin of merus reaching about half of carpus, triangu-

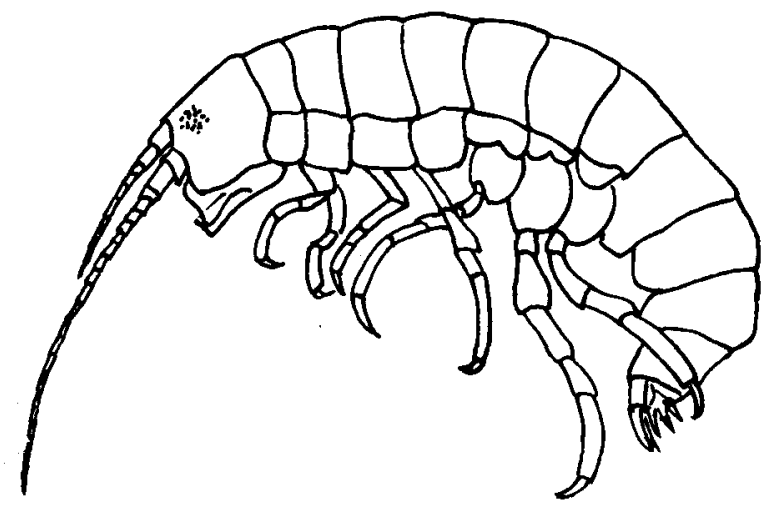

$1.0 \mathrm{~mm}$

Fig. 15. Hyale sp. (no.3), (2.3 mm in body length). Lateral view of body. 

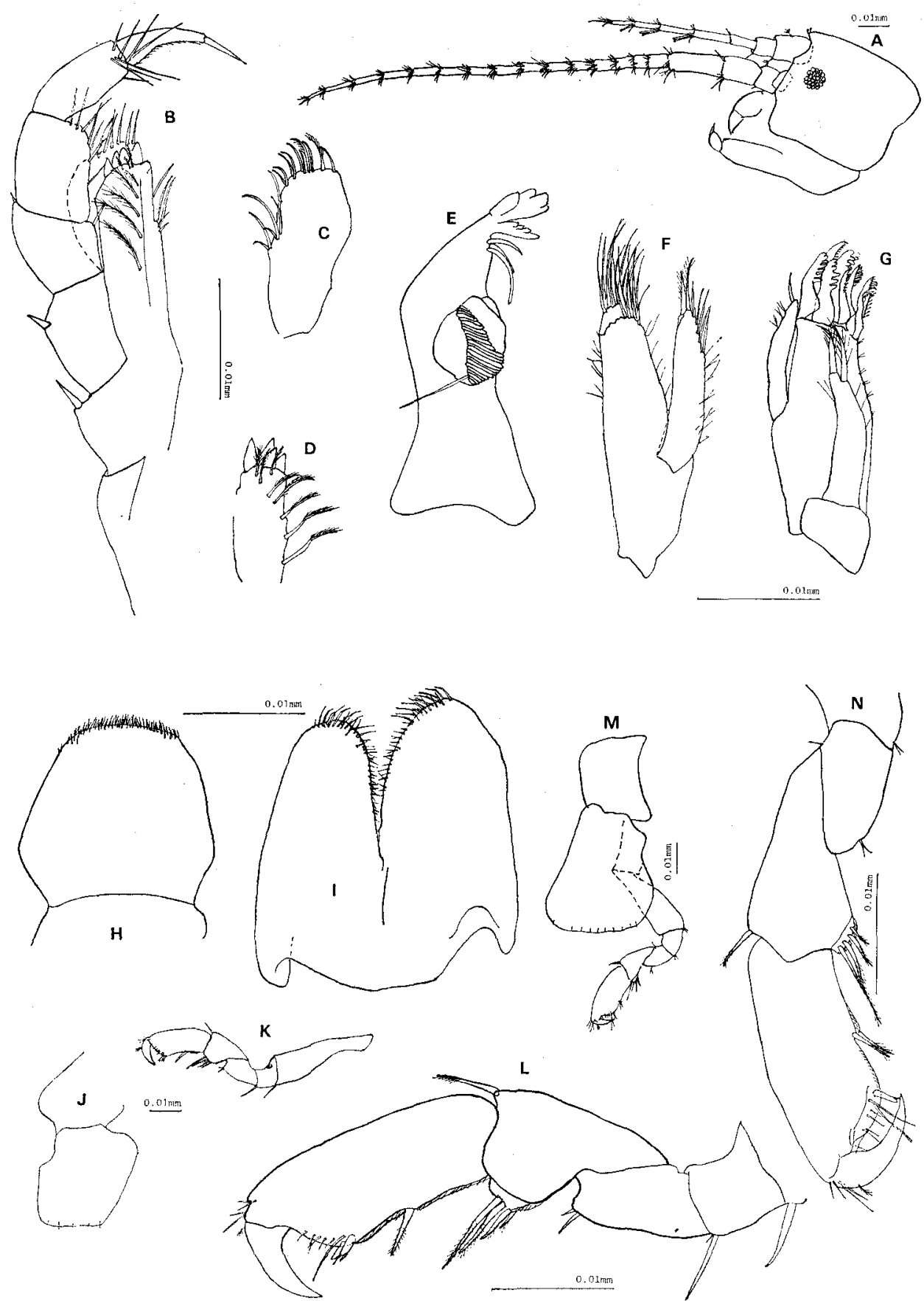

Fig. 16. Hyales sp. (no. 3,) (2.3 mm in body length). A, head and antennae; B, maxilliped; C, outer lobe of maxilliped; D, inner lobe of maxilliped; E, mandible; F, maxilla 2; G, maxilla $1 ; \mathrm{H}$, upper lip; I, lower lip; J, coxa 2; K, gnathopod 2; L, gnathopod 2; M, gnathopod 1 and peraeopod $1 ; \mathrm{N}$, gnathopod 1 . 

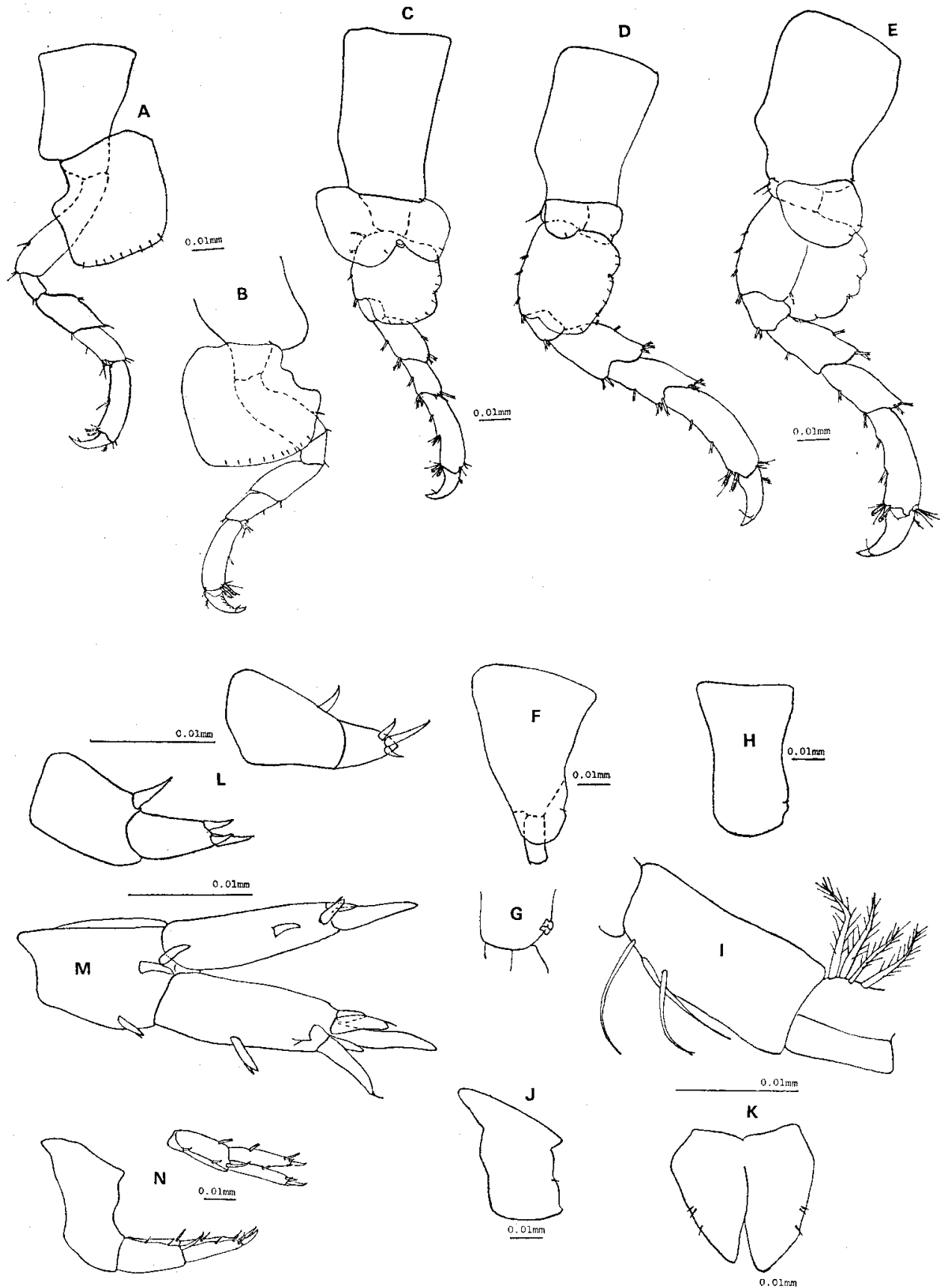

Fig. 17. Hyale sp. (no. 3), (2.3 mm in body length). A, peraeopod 1 and peracon 3; B, peraeopod 2 and peraeon 4; $\mathrm{C}$, peraeopod 3 and peraeon 5; D, peraeopod 4 and peraeon 6: $\mathrm{E}$, peraeopod 5 and peraeon $7 ; \mathrm{F}$, pleon $1 ; \mathrm{G}$, accessories of peduncle of pleopod $1 ; \mathrm{H}$, pleon 2; 1 , peduncle of pleopod $2 ; \mathrm{J}$, pleon $3 ; \mathrm{K}$, telson; L, uropod $3 ; \mathrm{M}$, uropod 2; $\mathrm{N}$, urosome 1 and uropod 1. 
lar, but round, with two setae, anterior margin with one seta. Carpus triangular, with one plumose seta on antero-distal angle, having small postero-distal lobe with four plumose setae. Propod rectangular, length longer than twice as long as width, posterior margin having small concavity which is defined medially by small lobe with two plumose setae. Palm oblique, defined by one stout spine, with two long setae and five short setae. Dactyl subequal to palm.

Gnathopod 2: Coxa 2 rectangular, lower margin shorter than basal margin, moderate posterior concave not reaching half of posterior margin. Gnathopod 2 very similar to gnathopod 1. Basis occupying half of gnathopod 2. Postero-distal seta of basis and ischium stout and long. Posterior margin of propod with one plumose seta medially. Palm defined by two stout spines.

Peraeopod 1: Coxa 3 rectangular, concave of posterior margin deep, not reaching medially. Basis with a set of two lateral setae and one of two distal setae in tandem on posterior margin. Ischium rectangular, with postero-distal seta. Merus with one proximal spine, one distal seta on anterior margin and one seta on postero-distal margin, twice as long as ischium, proximal and distal width twice as broad as basal margin. Carpus as long as merus, with two distal setae on anterior margin and one proximal seta and four distal setae on posterior margin. Propod shorter than basis, with a set of two proximal setae on posterior margin, two distal locking spines and one seta, with two setae on antero-distal margin. Dactyl unguiculate, with one minute seta on inner margin and one plumose seta on outer margin.

Peraeopod 2: Coxa 4 rectangular, posterior margin deep, complex sinuous, medially expanded. Peraeopod 2 very similar to peraeopod 1, but smaller than the latter. Merus lacking proximal spine.

Peraeopod 3: Anterior lobe of coxa 5 a few larger than posterior one, but lobes with one minute seta respectively. Basis rectangular, width as long as length, posterior margin concave , bearing minute seta on distal margin. Both sides of merus with lateral spines and distal spines respectively. Carpus with one lateral spines and four distal spines on anterior margin, with three spines on posterior margin. Propod subequal to basis in length, with two spines in tandem on anterior lateral margin and two locking spines. Dactyl similar to peraeopod 1 .

Peraeopod 4: Both lobes of coxa 6 subequal in size, with one minute seta respectively. Basis rectangular, having one small concave with minute seta, length longer than width. Ischium with two distal spines on anterior margin. Merus with two lateral spines in tandem and three distal spines on posterior margin and two distal spines on anterior margin. Carpus with antero-distal spine, three antero-distal spines and four postero-distal spines. Propod longer than basis, with two spines in tandem and two locking spines on anterior margin. Dactyl similar to one of peraeopod 1.

Peraeopod 5: Coxa 7 semi-circular, with two minute setae on posterior angle. Peraeopod 5 the largest of the peraeopods. Posterior margin of basis very expanded, crenualte, each concave with minute seta, center of inner distal margin with large spine. Ischium with two antero-distal spines. Merus with one antero-lateral spine, one postero-lateral spine and two postero-distal spines. Carpus with one antero-lateral 
and antero-distal spines and two postero-distal spines. Propod longer than basis, with two lateral spines in tandem and two locking spines. Dactyl similar to one of peraeopod 1.

Pleon and pleopods: Epimeron 1 round, posterior margin sinuous, with minute seta. Peduncle of pleopod 1 with two accessories on postero-distal angle. Epimeron 2 rectangular, lower margin gently round, posterior margin sinuous, with minute seta. Epimeron 3 rectangular, having round tooth on posterior angle, posterior margin sinuous, with minute seta.

Uropod 1: Peduncle shorter than rami, inner margin with two spines in tandem, outer margin with one spine, apicomedial spine not stout. Both rami equal, with lateral spine and four terminal spines respectively.

Uropod 2: Peduncle half of rami, with one spine on outer margin and two spines on inner margin. Both rami equal in length, outer ramus with one lateral spine and five terminal spines, inner ramus with one lateral spine and three terminal spines.

Uropod 3: Peduncle with one large distal spine, larger and broader than rami. Rami with three terminal spines.

Telson: Telson deep cleft, both lobe with three minute setae.

Remarks.

Considerable number of female specimens were collected with male of probably five species of Hyale described above at the same sampling point. They must belong to some of those species, but the author could not distinguished any grouping in the females. Perhaps, divergence of morphological characters in females must be much less than those in males. In this paper, only the description and figures of examined species are given. Close examination of coupling specimens with well defined male must be the best way to determine the species position of such featureless females.

Materials examined.

426 females were collected in the Kabira Bay, Ishigaki Island, Okinawa, Japan, in July 1, 1977. Female which is described in this paper is $2.3 \mathrm{~mm}$ in body length. These specimens are preserved in Amakusa Marine Biological Laboratory, Kyushu University.

\section{LITERATURE CITED}

Barnard, J.L. 1954. Marine Amphipoda of Oregon. Oregon State Monographs, Studies in Zoology, 8: $1-103$.

1955. Gammaridean Amphipoda (Crustacea) in the Collections of Bishop Museum. Bernice P. Bishop Museum Bulletin, 215: 1-46.

1962. Benthic Marine Amphipoda of Southern California; Families Amphilochidae, Leucothoidae, Stenothoidae, Argissidae, Hyalidae. Pacific Naturalist, Vol. 3, No. 3; 116-163.

1965. Marine Amphipoda of Atolls in Micronesia. Proceedings of the United States National Museum, 117; 459-552.

1969a. The Families and Genera of Marine Gammaridean Amphipoda. United States National Museum Bulletin, 271; 1-535.

1969b. Gammaridean Amphipoda of the Rocky Intertidal of California: Monterey Bay to 
La Jolla. United States National Museum Bulletin, 258; 1-238.

1970. Sublittoral Gammaridea (Amphipoda) of the Hawaiian Islands. Smithsonian Contributions to Zoology, 34; 1-286.

1971. Keys $\mathrm{t}$ othe Hawaiian Marine Gammaridea, 0-30 Meters. Smithsonian Contributions to Zoology, 58; 1-135.

1974. Garmmaridean Amphipoda of Australia, Part II. Smithsonian Contribitions to Zoology, $139 ; 1-148$.

Bousfield, E.L. 1973. Shallow-Water Gammaridean Amphipoda of New England. Comstock Publishing Associates. pp. 312.

Chevreux, E. and Fage, P. 1925. Amphipodes. Fauna de France, 9; 1-488.

Chilton, C. et al. 1928. Fauna of the Chilka Lake. Amphipoda. Memoirs of the Indian Museum, Vol. V, 1915-1924; 521--558.

Griffiths, C.L. 1974. The Amphipoda of Southern Africa, Part 2. The Gammaridea and Caprellidea of South West Africa South of $20^{\circ} \mathrm{S}$. Annals of the South African Museum, 62(6); 169-208.

Hurley, D.E. 1957. Studies on the New Zealand Amphipodan Fauna. No. 14: The Genera Hyale and Allorchestes (Family Talitridae). Transactions of the Royal Society of New Zealand, 84; 903-933.

Iwasa, M. 1939. Japanese Talitridae. Journal of the Faculty of Science, Hokkaido Imperial University, Series 6, (Zoology), 6; 255-296.

Ledoyer, M. 1968. Amphipodes Gammariens de Quelques Biotopes de Substrat meuble de la Région de Tuléar. Étude Systematique et Écologique. Recueil des Travaux de la Station Marine D'Endoume. Fasc. hors serie Suppl. 8; 15-62.

1972. Amphipodes Gammariens Vivant dans les Alveoles des Constructions Organogenes Recifales Intertidals de la Région de Tuléar (Madagascar). Etude Systematique et Ecologique. Téthys, Suppl. 3; 165-285.

Nagata, K. 1959. Notes on Five Species of the Amphipod Genus Ampelisca from the Stomach Contents of the Triglid Fishes. Publications of the Seto Marine Biological Laboratory, VII(2); 263-278.

1960. Preliminary Notes on Benthic Gammaridean Amphipoda from the Zostera Region of Mihara Bay, Seto Inland Sea, Japan. Ibidem, VIII (1); 163-182.

1961a. A New Atylid Amphipod from Japan. Annotationes Zoologicae Japonenses. Vol. 34, No. $4 ; 216-218$.

1961b. Two New Amphipods of the Genus Eurystheus from Japan. Publications of the Seto Marine Biological Laboratory, IX(1); 31-36.

-1965a. Studies on Marine Gammaridean Amphipoda of the Seto Inland Sea. I. Ibidem, XIII (2); 131-170.

1965b. Studies on Marine Gammaridean Amphipoda of the Seto Inland Sea. II. Ibidem, $\mathrm{XIII}(3) ; 171-186$.

— 1965c. Studies on Marine Gammaridean Amphipoda of the Seto Inland Sea. III. Ibidem, XIII(4); 291-326.

1966. Studies on Marine Gammaridean Amphipoda of the Seto Inland Sea. IV. Ibidem, $\mathrm{XIII}(5) ; 327-348$.

Nayar, K. 1959. The Amphipoda of the Madras Coast. Bulletin of the Madras Government Museum, New Series, Natural History Section, Vol. VI, No. 3; 1-59, 16 Plates.

Sars, G.O. 1895. Amphipoda. An Account of the Crustacea of Norway with Short Description and Figures of All the Species. Vol. 1; vii 711, 240 Plates, 8 Supplementary Plates. Christiana and Cophenhagen.

Stebbing, T.R.R. 1899. VIII. Amphipoda from the Cophenhagen Museum and Other Sources. Part II. Transactions of the Linnean Society of London, Series 7, Zoology, 2; 397-432, Plates 30-35. 